\title{
Two Distinct Mechanisms Mediate Acute $\mu$-Opioid Receptor Desensitization in Native Neurons
}

\author{
Vu C. Dang, ${ }^{1}$ Ian A. Napier, ${ }^{1,2}$ and MacDonald J. Christie ${ }^{1,2}$ \\ ${ }^{1}$ Pain Management Research Institute and ${ }^{2}$ Brain and Mind Research Institute, The University of Sydney, New South Wales 2006, Australia
}

\begin{abstract}
Sustained stimulation of G-protein coupled receptors (GPCRs) leads to rapid loss of receptor function (acute desensitization). For many GPCRs including the $\mu$-opioid receptor (MOR), an accepted mechanism for acute desensitization is through G-protein coupled receptor kinase (GRKs) mediated phosphorylation of the receptor, which facilitates the binding of $\beta$-arrestins ( $\beta$ arrs) to the receptor and then promotes endocytosis. However, the mechanism(s) that mediate acute desensitization have not yet been well defined in native neurons. This study used whole-cell patch clamp recording of G-protein coupled inward-rectifying potassium (GIRK) currents to assay MOR function and identify mechanisms of acute MOR desensitization in locus ceruleus (LC) neurons. The rate and extent of MOR desensitization were unaffected by $\beta$ arr-2 knock-out. Disruption of GRK2 function via inhibitory peptide introduced directly into neurons also failed to affect desensitization in wild type or $\beta$ arr-2 knock-outs. Inhibition of ERK1/2 activation alone had little effect on acute desensitization. However, when both GRK2- $\beta$ arr-2 and ERK1/2 functions were disrupted simultaneously, desensitization of MOR was nearly abolished. Together, these results suggest that acute desensitization of MOR in native LC neurons is determined by at least two molecular pathways, one involving GRK2 and $\beta$ arr-2, and a parallel pathway mediated by activated ERK1/2.
\end{abstract}

\section{Introduction}

Agonist activation of G-protein coupled receptors (GPCRs) initiates receptor regulatory events that lead to acute desensitization of signaling during continuous agonist stimulation (Gainetdinov et al., 2004). For the $\mu$-opioid receptor (MOR), acute desensitization is thought to be required for development of opioid tolerance and influences development of dependence (Bohn et al., 1999, 2000; Finn and Whistler, 2001) Therefore, understanding mechanisms of desensitization may provide insights into the development these phenomena. Studies using heterologous expression systems have implicated GRKs and $\beta$-arrestins ( $\beta$ arrs) in desensitization (Shenoy and Lefkowitz, 2003; Gainetdinov et al., 2004), a process initiated by phosphorylation of agonist bound receptor by GRK2, which facilitates $\beta$ arr-2 interaction with the receptor, initiating endocytosis. After phosphorylation by GRK2 (Wang, 2000; Li and Wang, 2001) and perhaps GRK3 (Kovoor et al., 1998), MOR is thought to interact predominantly with $\beta$ arr-2 (Cheng et al., 1998). However, it remains uncertain whether GRK phosphorylation and/or subsequent $\beta$ arr- 2 binding, by preventing further receptor-G-protein interactions, are actually responsible for mediating MOR desensitization (Cheng et al., 1998). Attempts to establish the relevance of these molecular mecha-

Received 0ct. 3, 2008; revised Jan. 29, 2009; accepted Feb. 15, 2009.

This work was supported by the National Health and Medical Research Council of Australia (Program Grant 351446, Fellowship 511914 to M.J.C.) and New South Wales Spinal Cord Injury and Other Neurological Conditions Program Grant R1PG5. Special thanks to Dr. Billy Chieng for providing LC slices for Western blot analyses. We also thank Drs. Lefkowitz and Caron for supply of the $\beta$-arrestin-2 knock-out mice.

Correspondence should be addressed to MacDonald J. Christie, Brain and Mind Research Institute, M02G, The University of Sydney, NSW 2006, Australia. E-mail: macc@med.usyd.edu.au.

V. C. Dang's present address: Department of Psychiatry, University of California, San Francisco, Genentech Hall, Room N-216P, 600 16th Street, San Francisco, CA 94158.

DOI:10.1523/JNEUROSCI.4749-08.2009

Copyright $\odot 2009$ Society for Neuroscience $\quad 0270-6474 / 09 / 293322-06 \$ 15.00 / 0$ nisms in native neurons have been confounded because desensitization was not prevented by suppressing $\beta$ arr- 2 expression (Dang, 2006; Walwyn et al., 2007) or inhibition of MOR endocytosis (Arttamangkul et al., 2006). One challenge for isolating mechanisms of desensitization in native neurons may be redundancy in molecular mechanisms mediating GPCR regulation. For example, LC neurons express GRKs 2, 3, 5 (weak), and 6 (Arriza et al., 1992) as well as $\beta$ arr-1 (Fan et al., 2003), which could conceivably substitute for GRK2 and $\beta$ arr- 2 when their functions are disrupted.

In addition to GRK- $\beta$ arr dependent mechanisms, protein kinase C (PKC) and ERK1/2 activation can mediate or enhance MOR desensitization in heterologous expression systems (Schmidt et al., 2000; Bohn et al., 2002; Johnson et al., 2006). Together, these observations suggest either that MOR desensitization under different experimental conditions can occur via different molecular mechanisms (Bailey et al., 2006; Johnson et al., 2006) or, alternatively, MOR desensitization is mediated by multiple mechanisms in native neurons. To determine whether MOR desensitization is mediated by multiple molecular mechanisms, this study used patch-clamp recordings of the activation of GIRK channels by MOR in brain slices containing LC neurons from $\beta$ arr-2 wild type (w.t.) and knock-out ( $\beta$ arr-2 k.o.) mice. LC neurons homogenously express MOR but no other opioid receptors, making them useful for studying MOR regulation in native neurons (Connor et al., 2004; Bailey et al., 2006). In LC neurons, MOR activates GIRK channels via a rapid, membrane delimited interaction with $G \beta \gamma$ subunits, providing a sensitive and direct assay of receptor function and desensitization when studied with appropriate agonist concentrations (Connor et al., 2004). The present results show that acute loss of MOR function in LC neurons is mediated by at least two independent molecular mecha- 


\section{ME concentration-response}

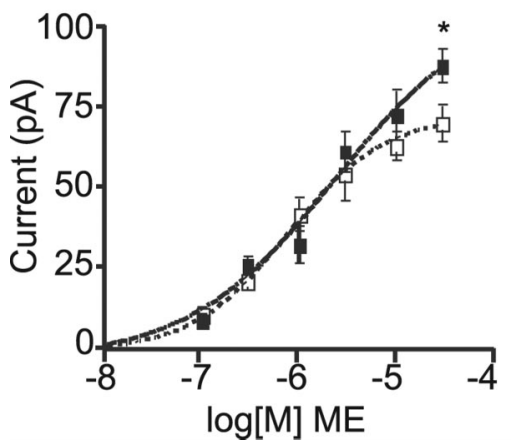

Figure 1. Basal $M O R$ coupling efficacy is reduced in $L C$ neurons from $\beta$ arr- 2 k.o. mice. Concentration-response curve of ME-activated GIRK in LC neurons from w.t. mice ( $\mathbf{\square})$ and $\beta$ arr-2 k.o. mice $(\square)$. The $\mathrm{EC}_{50}$ was unaffected but peak $\mathrm{ME}(30 \mu \mathrm{m})$-activated current was greater in w.t. than $\beta$ arr- 2 k.o. mice (means \pm SEM, $n=4-12$ neurons per data point, ${ }^{*} p<0.05$, Bonferroni post hoc test).

nisms; one is ERK1/2-dependent and the second mediated by GRK2- $\beta$ arr-2. Therefore, desensitization is prevented only when both ERK1/2 and $\beta$ arr-2 dependent mechanisms are blocked simultaneously.

\section{Materials and Methods}

Electrophysiology. Whole-cell recordings were made from 167 routinely genotyped, 5- to 12-week-old $\beta$ arr-2 knock-out mice from Drs. Lefkowitz and Caron (Duke University) (Bohn et al., 2000), or their wild-type littermates (w.t., C57BL6 background). LC slices were prepared as previously described for rats (Ishimatsu and Williams, 1996). Briefly, mice were anesthetized with isoflourane (4\% in air), decapitated, brains were removed and blocked. Horizontal Vibratome (Leica1000) sections $(200-220 \mu \mathrm{m})$ were prepared at $4^{\circ} \mathrm{C}$, then incubated in extracellular solution (ACSF, $60 \mathrm{~min}, 37^{\circ} \mathrm{C}$ ). ACSF contained the following (in mM): $126 \mathrm{NaCl}, 2.5 \mathrm{KCl}, 2.4 \mathrm{CaCl}_{2}, 1.2 \mathrm{MgCl}_{2}, 1.2 \mathrm{NaH}_{2} \mathrm{PO}_{4}, 21.4$ $\mathrm{NaHCO}_{3}, 11.1$ glucose, $95 \% \mathrm{O}_{2}-5 \% \mathrm{CO}_{2}$ at $37^{\circ} \mathrm{C}$. Pipette (2-4 M $\Omega$ ) solution contained the following (in mM): $115 \mathrm{~K}$ MES (2-[morpholino]ethane-sulfonic acid), $20 \mathrm{KCl}, 1.5 \mathrm{MgCl}_{2}, 10$ BAPTA, 5 HEPES, $4 \mathrm{Mg}$ ATP and $0.4 \mathrm{Na}-\mathrm{GTP}, \mathrm{pH}=7.3-7.4$. Voltage-clamp recordings of visualized LC neurons (infrared Nomarski optics, holding potential -55 to $-60 \mathrm{mV}$ ) were acquired using Axograph X (Axograph Scientific) and filtered at $20-100$ hertz. Bestatin $(10 \mu \mathrm{M})$ and thiorphan $(1 \mu \mathrm{M})$ were included in all experiments using [Met ${ }^{5}$ enkephalin (ME). All experiments were approved by the Royal North Shore Hospital/University of Technology Sydney Ethics Committee, which complies with National Health and Medical Research Council of Australia guidelines.

Statistics and curve fitting. Data were analyzed using PRISM (GraphPad Software). Values are given as mean \pm SEM. Statistical comparisons were made with $\mathrm{t}$ tests (for 2 groups) or two-way ANOVA with Bonferroni's post hoc tests and considered significant if $p<0.05$. When possible, rate constants were estimated using Axograph X simple exponential fit of the decline of the ME $(30 \mu \mathrm{M})$ current. The time constants were $(\tau)$ $\sim 8.2 \pm 1 \mathrm{~min}(n=10)$ and $\sim 8.5 \pm 1 \min (n=11)$ in w.t. and $\beta$ arr- 2 k.o., respectively.

Reagents were from the following: $\mathrm{Met}^{5}$-enkephalin, thiorphan, bestatin, chelerythrin, wortmanin; Sigma. Naloxone, UK14304; RBI. PD98059, U0126, LY29004; Tocris, morphine HCl; GSK. The GRK2 inhibitory peptide sequence W643-S670 (Ac-WKKELRDAVREAQQLVQRVPKMKNKPRS-NH2, > 95\% purity) (Koch et al., 1994; Li et al., 2001) was custom synthesized by Auspep.

\section{Results}

\section{$\boldsymbol{\beta}$-Arrestin-2 deletion does not affect acute desensitization of MOR}

Basal MOR function was first evaluated in LC neurons from w.t. and $\beta$ arr- 2 k.o. mice. Figure 1 shows that basal MOR coupling

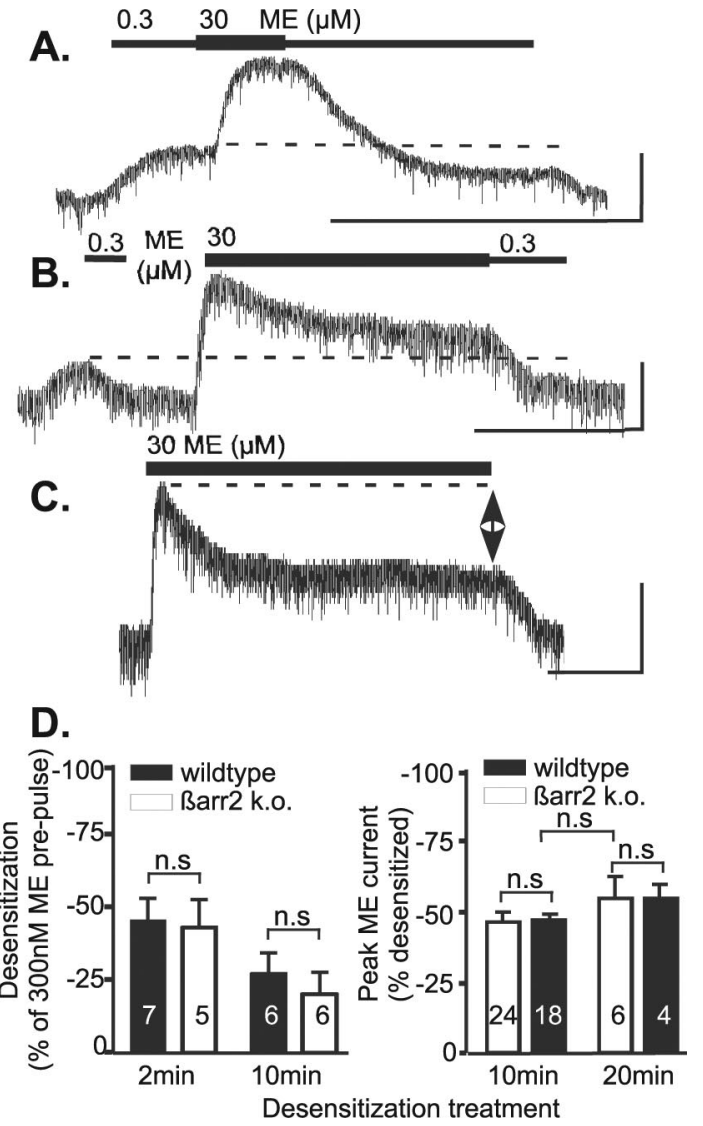

Figure 2. $\quad \beta$ arr-2 deletion did not affect MOR desensitization (all example current traces taken from $\beta$ arr-2 k.o. mice). A, GIRK current activated by a submaximal concentration of ME $(300 \mathrm{~nm}$ ) to sensitively probe receptor function was reduced after brief exposure to ME ( 2 min; 30 $\mu \mathrm{M})$. $\boldsymbol{B}$, Desensitization treatment with $\mathrm{ME}(30 \mu \mathrm{m})$ for 10 min produced a rapid reduction of the peak GIRK current and reduction of current activated by the submaximal concentration of ME (300 nM). C, Desensitization treatment with ME (30 $\mu \mathrm{M})$ for $20 \mathrm{~min}$ did not produce greater desensitization than 10 min desensitization treatment. $\boldsymbol{D}$, Data summary of MOR desensitization after each desensitization treatment in w.t. $(\square)$ and k.0. $(\square)$ mice (mean \pm SEM, $n$ shown in bars, $t$ tests; n.S., nonsignificant; all $p>0.05$; calibration, 5 min; $25 \mathrm{pA}$ ).

efficacy in LC neurons from $\beta$ arr-2 k.o. mice is slightly less efficacious than in neurons from w.t. mice, i.e., GIRK activation by a maximal concentration of $\mathrm{ME}\left(10-30 \mu \mathrm{M}\right.$, but not the $\left.\mathrm{EC}_{50}\right)$ was slightly depressed in neurons from $\beta$ arr-2 k.o. mice. Consistent with a slightly reduced basal MOR coupling efficacy in LC neurons from $\beta$ arr- 2 k.o. mice a supramaximal concentration of the partial agonist, morphine $(10 \mu \mathrm{M})$ produced less activation of GIRK in neurons from $\beta$ arr-2 k.o. mice (w.t.: $26 \pm 4$ pA, $n=10$ and $\beta$ arr-2 k.o.: $16 \pm 3$ pA, $n=5, p<0.007)$.

Experiments were then conducted to determine the mechanisms of MOR desensitization. Surprisingly, $\beta$ arr-2 deletion had no effect on the rate or extent of agonist-induced acute desensitization, suggesting $\beta$ arr- 2 is not required for MOR desensitization in LC (Fig. 2). As previously reported in LC from rat and mouse (Arttamangkul et al., 2006, 2008), brief treatment with supramaximal (Fig. 1) concentrations of $\mathrm{ME}(10-30 \mu \mathrm{M} ; \leq 2$ $\mathrm{min}$ ) reduced the current activated by a submaximal (Fig. 1) concentration of ME (300 nM) to $45 \pm 8 \%(n=7)$ and $43 \pm 10 \%$ $(n=5)$ of the prepulse response for neurons from w.t. and $\beta$ arr- 2 k.o. mice, respectively (Fig. $2 A$ ). When slices from both w.t. and $\beta$ arr- 2 k.o. animals were treated with $\mathrm{ME}(30 \mu \mathrm{M})$ for $10 \mathrm{~min}$, the ME-activated current peaked then rapidly declined (Fig. $2 B$ ) to the same extent in neurons from w.t. and $\beta$ arr- 2 k.o. mice [ $46 \pm$ 

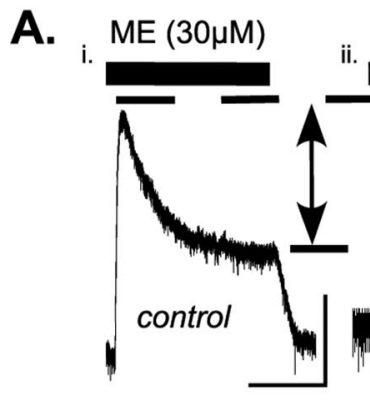

B.
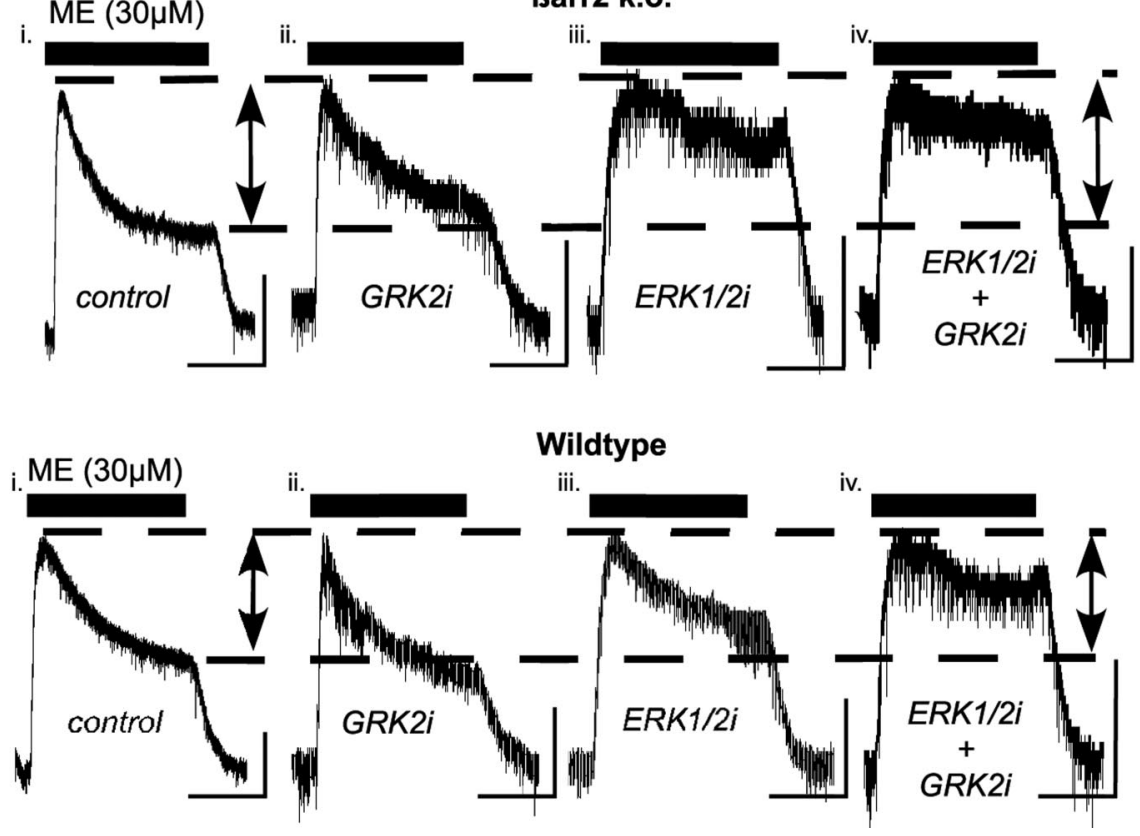

iii.
Barr2 k.o.
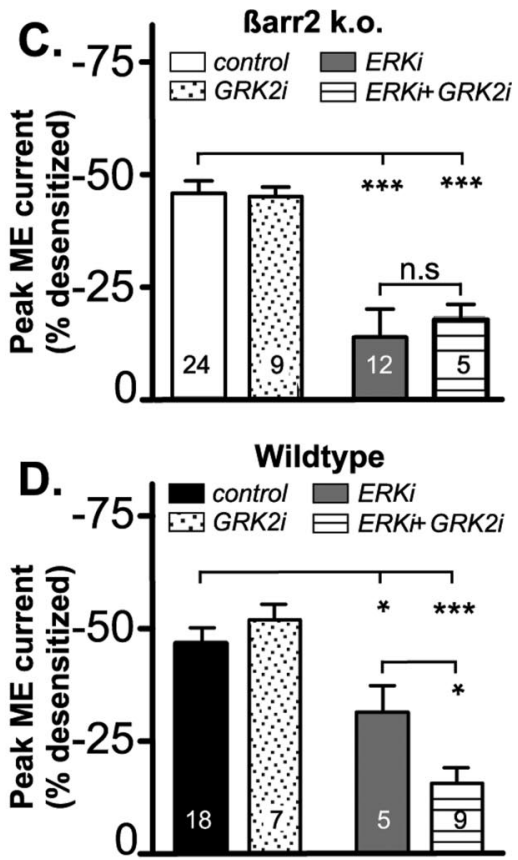

Figure 3. MOR desensitization is mediated independently by ERK1/2 and $\beta$ arr-2. $\boldsymbol{A}-\boldsymbol{D}$, Recordings of $L($ neurons from $\beta$ arr- 2 k.0. $(\boldsymbol{A}, \boldsymbol{C})$ and w.t. ( $\boldsymbol{B}, \boldsymbol{D})$ mice show desensitization during exposure to ME (30 $\mu \mathrm{m}, 10 \mathrm{~min}$ ). GRK2i alone had no effect on MOR desensitization in $\beta$ arr-2 k.o. (Aii, $\boldsymbol{C}$ ) or w.t. (Bii, $\boldsymbol{D}$ ). ERK1/2 inhibitors (ERK1/2i) alone nearly abolished MOR desensitization in $\beta$ arr-2 k.0. (Aiii, C) but only weakly reduced MOR desensitization in w.t. (Biii, D). Aiv, Biv, Blocking GRK2 and ERK1/2 together nearly abolished MOR desensitization in both groups (C, D). Calibrations: 5 min, $25 \mathrm{pA}$. Arrows denote desensitized currents. C, $\boldsymbol{D}$, Mean \pm SEM, $n$ shown inside bars, $t$ tests; $n$.S, nonsignificant; $p>0.05,{ }^{*} p<0.05,{ }^{* * *} p<0.0001$.

$3 \%(n=24)$ and $46 \pm 2 \%(n=18)$, respectively]. A more sensitive assay of MOR desensitization is to compare the current induced by a submaximal concentration of ME (300 nM) (Fig. 1A) before and soon after the desensitization treatment (Connor et al., 2004). Assessment of MOR function in this manner (ME 30 $\mu \mathrm{M}, 10 \mathrm{~min}$ ), also produced similar desensitization in LC neurons from w.t. and $\beta$ arr-2 k.o. mice (Fig. 2D). Extending exposure to $\mathrm{ME}(30 \mu \mathrm{M})$ to $20 \mathrm{~min}$ did not increase the magnitude of desensitization (Fig. $2 C, D$ ) in neurons from w.t. or $\beta$ arr-2 k.o. mice (see also Materials and Methods for rate). As consistently reported for LC neurons (Williams et al., 2001), MOR desensitization was largely homologous, i.e., the ability of the $\alpha_{2}$ adrenoceptor agonist, UK14034 ( $3 \mu \mathrm{M})$ to evoke a maximal GIRK current was unaffected by MOR desensitization ( $71 \pm 7 \%$ of peak ME current without desensitization $(n=5)$, and $62 \pm 6 \%$ after 10 min desensitization, $n=10$ ).

ERK1/2 mediates acute MOR desensitization in LC neurons of $\boldsymbol{\beta}$-arrestin-2 knock-out mice

Experiments were then performed to determine whether MOR desensitization is mediated by phosphorylation by GRKs or other kinases which occurs before $\beta$ arr- 2 binding to the receptor. To inhibit GRK2 phosphorylation in $\beta$ arr-2 k.o. mice, a synthetic GRK2 inhibitory peptide (GRK2i, $100 \mu \mathrm{M})$, which corresponds to $G \beta \gamma$-binding domain of GRK2 and specifically inhibits $G \beta \gamma$ activation of GRK2 in neurons (Koch et al., 1994; DiversePierluissi et al., 1996; Li and Wang, 2001), was dialyzed into LC neurons via the recording electrode for $\geq 50 \mathrm{~min}$. Disruption of GRK2 function did not affect ME-induced ( $30 \mu \mathrm{M}, 10 \mathrm{~min}) \mathrm{MOR}$ desensitization in $\beta$ arr- 2 k.o. neurons (Fig. 3 Aii). This challenges the notion that acute homologous MOR desensitization is mediated exclusively by the GRK2- $\beta$ arr- 2 pathway because disruption of the pathway with either GRK2i or deletion of $\beta$ arr- 2 failed to affect desensitization.
Depending on the experimental conditions, MOR desensitization can be modulated by protein kinases such as PKC and PI3K (Tan et al., 2003; Bailey et al., 2006). However, these studies showed that blocking PKC or PI3K individually failed to affect acute desensitization mediated by endogenous opioid peptides. Consistent with these reports, inhibition of PKC or PI3K also failed to prevent ME-induced ( $30 \mu \mathrm{M}, 10 \mathrm{~min}$ ) MOR desensitization in $\beta$ arr-2 k.o. mice (Fig. 4).

Agonist activation of MOR has been shown to increase ERK1/2 phosphorylation in some heterologous expression systems (Eitan et al., 2003; Macey et al., 2006; Ligeza et al., 2008) and in LC neurons in vivo (Eitan et al., 2003). Western blot analyses of LC nucleus microdissected from brain slices revealed a high level of basal phosphorylated ERK1/2 and activation of MOR by ME (30 $\mu \mathrm{M}, 10 \mathrm{~min}$ ) induced a very small increase $(\sim 10 \%)$ of phospho-ERK levels (see supplemental Fig. 1, available at www. jneurosci.org as supplemental material). The ERK1/2 inhibitors, PD98059 and U0126 (10 $\mu \mathrm{M})$, decreased phospho-ERK levels (supplemental Fig. 1, available at www.jneurosci.org as supplemental material), providing a positive control for physiological experiments.

LC neurons were dialyzed with PD98059 or U0126 (10 $\mu \mathrm{M})$, for $\geq 50$ min before the desensitization treatment. To control for possible nonspecific effects of ERK1/2 inhibition on GIRK channels, a pulse of ME (300 nM) was applied immediately after establishing whole-cell mode and again immediately before the desensitization experiments. No decline of the ME (300 nM) induced GIRK current was detected during intracellular incubation with ERK $1 / 2$ inhibitors ( $101 \pm 8 \%$ of initial response, $n=6$ ). Blocking ERK1/2 had a small but significant $(p<0.05)$ effect on the magnitude of desensitization in LC neurons from w.t. mice but, in contrast, nearly abolished acute MOR desensitization in $\beta$ arr-2 k.o. mice (Fig. 3Aiii,Biii). This suggests that ERK1/2 can mediate 


\section{A. ME}

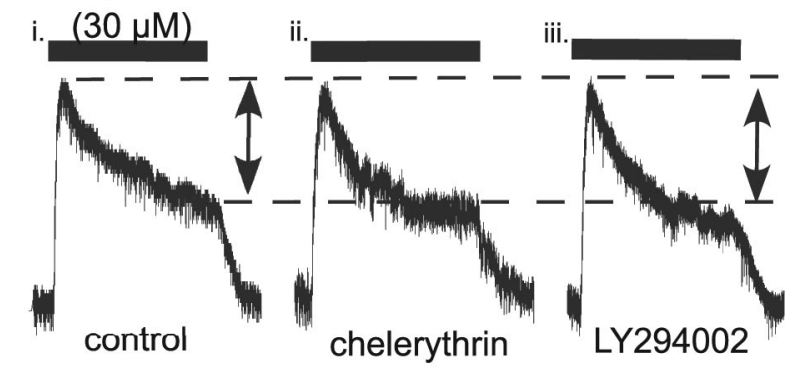

B.

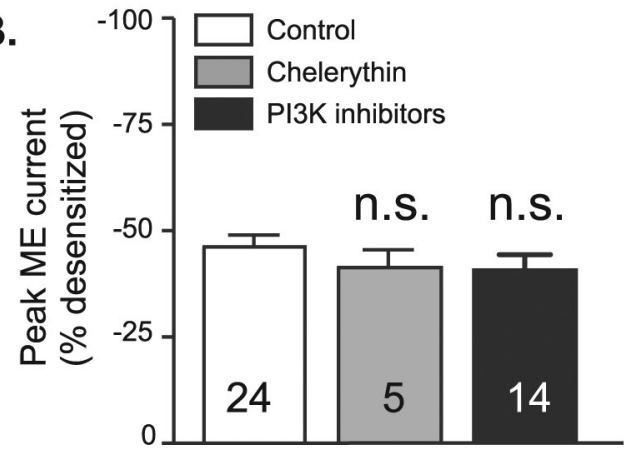

Figure 4. Protein kinase $\mathrm{C}$ and $\mathrm{PI} 3$ kinase activation do not mediate desensitization. $\boldsymbol{A}$, Whole-cell current recordings from $\beta$ arr- 2 k.o. mice: (i) control, (ii) in the presence of PKC inhibitor (chelerythrin; $10 \mu \mathrm{M}$ ), (iii) PI3K inhibitor (LY294002 or wortmanin; $10 \mu \mathrm{m}$ ). $\boldsymbol{B}$, Summary showing that blocking PKC or PI3K did not change ME induce MOR desensitization (means $\pm \mathrm{SEM}, n$ values shown in bars). n.S., Nonsignificant.

rapid loss of MOR function in LC neurons only in the absence of Barr-2.

\section{Two distinct mechanisms mediate acute MOR desensitization} in LC neurons from $\boldsymbol{\beta}$-arrestin- 2 wild-type mice

Having shown that acute desensitization in LC neurons from Barr-2 k.o. mice is mediated by ERK1/2, experiments were performed to determine if the same mechanism occurs in neurons from w.t. mice. LC neurons from w.t. mice were dialyzed with GRK2i ( $100 \mu \mathrm{M} ; \geq 50 \mathrm{~min})$ to disrupt GRK2 function and thereby prevent $\beta$ arr-2 interaction with MOR during ME (30 $\mu \mathrm{M}, 10$ min) treatment. Consistent with the results for neurons from Barr-2 k.o. mice (Fig. 3Aii,Bii), disruption of $\beta$ arr-2 binding to MOR, via GRK2 inhibition, had no effect on ME-induced acute desensitization in neurons from w.t. mice.

Given that disruption of $\beta$ arr-2 failed to prevent acute desensitization and that inhibition of ERK1/2 alone had only a marginal effect in neurons from w.t. mice suggests that each mechanism can independently mediate acute receptor desensitization. If so, both processes would need to be inhibited concurrently to ablate acute desensitization of MOR in LC neurons. Simultaneous inhibition of both GRK2 and ERK1/2 nearly abolished ME-induced acute desensitization of LC neurons from w.t. mice (Fig. 3Biv). In w.t. neurons, desensitization with $\mathrm{ME}(30 \mu \mathrm{M}, 10$ min), in the presence of GRK2i and either ERK1/2 inhibitor, reduced the peak current by only $15 \pm 4 \%$ (Fig. 3Biv). When the same experiment was conducted in $\beta$ arr- 2 k.o. mice, desensitization was the same as that found in experiments with ERK1/2 inhibitor alone $(17 \pm 3 \%)$. Together, these results establish that either ERK1/2 activity or $\beta$ arr-2 can independently desensitize MOR in LC neurons, so both processes must be blocked to prevent desensitization.

\section{Discussion}

This study establishes that rapid desensitization of MOR in LC neurons is mediated by at least two distinct mechanisms independently involving ERK1/2 activity and GRK2- $\beta$ arr-2. This reconciles and extends previous reports that deletion of $\beta$ arr- 2 does not prevent acute MOR desensitization (Dang and Christie, 2006; Walwyn et al., 2007; Arttamangkul et al., 2008). Indeed, when MOR function was probed with a low concentration of agonist (ME; $300 \mathrm{nM}$ ) to avoid any potential influence of spare receptors (Connor et al., 2004), the rate and extent of desensitization were unaffected by $\beta$ arr- 2 deletion.

While inhibition of GRK2, $\beta$ arr-2 or ERK1/2 function individually failed to prevent MOR desensitization, disruption of both together (and ERK1/2 only in $\beta$ arr- 2 k.o. mice) nearly abolished desensitization. This finding shows that regulation of MOR function during agonist stimulation is mediated by at least two mechanisms in LC neurons. Therefore, MOR desensitization mediated by an endogenous opioid peptide is more complex than previously thought. The failure of GRK2 inhibition alone to prevent MOR desensitization in neurons from $\beta$ arr- 2 k.o. mice also suggests that phosphorylation of MOR by GRK2 cannot account for the persistence of desensitization, therefore another mechanism (ERK-dependent) must be responsible.

The finding that ERK1/2 inhibitors ablate acute desensitization (10 min) only when $\beta$ arr-2 association with MOR is prevented, either by $\beta$ arr- 2 deletion or GRK 2 inhibition in w.t. mice, indicates that ERK1/2-dependent desensitization occurs with a rate similar to and in parallel with GRK- $\beta$ arr- 2 binding mechanisms. The specific process for the ERK1/2-dependent mechanism is not yet known but MOR desensitization, internalization and phosphorylation have all been reported to be prevented by ERK1/2 inhibition in some heterologous expression systems (Schmidt et al., 2000). Like the initial events of the GRK- $\beta$ arr-2 interaction, signaling by ERK1/2 may therefore prevent coupling of MOR to effectors by phosphorylating MOR at sites not occupied by $\mathrm{G} \alpha$-subunits (Schmidt et al., 2000). Alternatively, ERK1/2 may act indirectly to mediate desensitization via phosphorylation of $\mathrm{G} \alpha$-interacting protein (GAIP), a regulator of G-protein signaling (RGS) by potentiating the rate of GTP hydrolysis, as has been reported in some cell types (Ogier-Denis et al., 2000).

Agonist-induced MOR activation of ERK1/2 can be mediated by both $\mathrm{G} \beta \gamma$ subunit- and $\beta$ arr-2-dependent mechanisms (Zheng et al., 2008). The finding that ME-mediated MOR desensitization in neurons from the $\beta$ arr- 2 k.o. is ERK1/2 dependent suggests that $\beta$ arr- 2 mediated ERK1/2 phosphorylation is not essential for this process. PI3 kinase and PKC may also be involved in $\mathrm{G} \beta \gamma$-dependent ERK1/2 phosphorylation and these kinases could modulate MOR desensitization (Tan et al., 2003; Bailey et al., 2006). However, inhibition of PI3 kinase or PKC had no impact on the extent of desensitization in $\beta$ arr- 2 k.o. mice. It is possible that constitutive ERK1/2 activation in LC neurons is sufficient to mediate ERK1/2- dependent desensitization. Compared with constitutively phosphorylated ERK1/2, MOR-agonist mediated ERK1/2 phosphorylation in LC in slices was relatively small $(\sim 10 \%)$. This is not surprising because phosphorylation of ERK1/2 by MOR-agonists may be indirect in vivo (Eitan et al., 2003) and in some heterologous expression systems (Mouledous et al., 2004).

Inhibition of ERK1/2 unmasked MOR desensitization that could then be blocked by specific disruption of GRK2 or $\beta$ arr-2 function, indicating that these regulatory proteins functionally 
associate with MOR in native LC neurons. Previously, there has been no clear demonstration of which GRK and arrestin isoforms are important in native neurons where multiple GRKs and arrestins are expressed endogenously in a single neuron (Bohn et al., 2004; Gainetdinov et al., 2004). In the present study, inhibition of ERK1/2 nearly abolished ME mediated acute desensitization in LC neurons from $\beta$ arr-2 k.o. mice. Similarly, in neurons from w.t. mice, MOR desensitization was prevented when ERK1/2 was inhibited in conjunction with the disruption of GRK2 function to prevent $\beta$ arr recruitment. Because LC neurons also express $\beta$ arr-1 (Fan et al., 2003), it is possible that MOR desensitization is mediated through $\beta$ arr- 1 when $\beta$ arr- 2 is deleted. However, the present results suggest that $\beta$ arr- 1 does not substitute for $\beta$ arr- 2 in LC neurons from $\beta$ arr- 2 k.o. mice because when ERK1/2 was inhibited, MOR desensitization was nearly abolished. Additionally, inhibition of EKR1/2 has been reported to increase $\beta$ arr-1 activation and function (Lin et al., 1999). As such, if $\beta$ arr-1 did substitute for $\beta$ arr- 2 in the k.o. mice then ERK1/2 inhibition would have been expected to facilitate MOR desensitization, but the opposite effect was observed. These findings are consistent with reports that MOR interacts predominantly with $\beta$ arr- 2 in heterologous expression systems (Cheng et al., 1998). Weak interactions of MOR with $\beta$ arr-1 have been reported, particularly when $\beta$ arr-2 is deleted (Schulz et al., 1999), so it is possible that the very small residual desensitization remaining after blocking both ERK1/2 and GRK2- $\beta$ arr-2 mechanisms is mediated by $\beta$ arr- 1 .

The present study also suggests that GRK2 is likely to be the major isoform of GRKs that phosphorylates MOR and recruits Barr-2 in LC neurons (Erdtmann-Vourliotis et al., 2001). This interpretation is supported by the observation that MOR desensitization was ablated in neurons from w.t. animals when disruption of GRK2 function was performed in conjunction with ERK1/2 inhibition. While it is not certain that the effect of GRK2i is completely specific for GRK2, studies in heterologous expression systems suggest that it does not interact with GRK3, 5 or 6 (Koch et al., 1994; Diverse-Pierluissi et al., 1996). Furthermore, when the same concentration of GRK2 $i$ as used here was introduced into other neurons, no disruption of GRK3 function was found (Diverse-Pierluissi et al., 1996). Heterologous expression studies have shown that coexpression of GRK2, -3 , or -5 with $\beta$ arr-2 can produce agonist dependent acute MOR desensitization (Kovoor et al., 1998), so it remains possible that the GRK3 or 5 contribute to the small residual desensitization remaining after blocking both ERK1/2 and GRK2 in neurons from w.t. mice.

The present results provide further understanding of GPCR and, more specifically, MOR regulation by identifying multiple mechanisms in native neurons responsible for acute desensitization mediated by the opioid peptide, ME. Whether both mechanisms operate in all opioid sensitive neurons is not known. The observation that desensitization also persists in sensory neurons from $\beta$ arr-2 k.o. (Walwyn et al., 2007) reinforces suggests multiple mechanisms mediate desensitization in neurons other than LC [but see Li and Wang (2001)]. Differential adaptations to ERK1/2- and GRK2- $\beta$ arr-2-function might also be responsible for the enhanced desensitization and the failure of MOR to recover from desensitization that result in reduced MOR signaling after chronic morphine treatment (Dang and Williams, 2004). Understanding these specific adaptations may facilitate the development of drugs that can reduce tolerance.

\section{References}

Arriza JL, Dawson TM, Simerly RB, Martin LJ, Caron MG, Snyder SH, Lefkowitz RJ (1992) The G-protein-coupled receptor kinases $\beta$ ARK1 and $\beta$ ARK2 are widely distributed at synapses in rat brain. J Neurosci 12:4045-4055.

Arttamangkul S, Torrecilla M, Kobayashi K, Okano H, Williams JT (2006) Separation of $\mu$-opioid receptor desensitization and internalization: endogenous receptors in primary neuronal cultures. J Neurosci 26:4118-4125.

Arttamangkul S, Quillinan N, Low MJ, von Zastrow M, Pintar J, Williams JT (2008) Differential activation and trafficking of $\mu$-opioid receptors in brain slices. Mol Pharmacol 74:972-979.

Bailey CP, Smith FL, Kelly E, Dewey WL, Henderson G (2006) How important is protein kinase $\mathrm{C}$ in mu-opioid receptor desensitization and morphine tolerance? Trends Pharmacol Sci 27:558-565.

Bohn LM, Lefkowitz RJ, Gainetdinov RR, Peppel K, Caron MG, Lin FT (1999) Enhanced morphine analgesia in mice lacking beta-arrestin 2. Science 286:2495-2498.

Bohn LM, Gainetdinov RR, Lin FT, Lefkowitz RJ, Caron MG (2000) Muopioid receptor desensitization by beta-arrestin-2 determines morphine tolerance but not dependence. Nature 408:720-723.

Bohn LM, Lefkowitz RJ, Caron MG (2002) Differential mechanisms of morphine antinociceptive tolerance revealed in $\beta$ arrestin-2 knock-out mice. J Neurosci 22:10494-10500.

Bohn LM, Dykstra LA, Lefkowitz RJ, Caron MG, Barak LS (2004) Relative opioid efficacy is determined by the complements of the $G$ proteincoupled receptor desensitization machinery. Mol Pharmacol 66:106-112.

Cheng ZJ, Yu QM, Wu YL, Ma L, Pei G (1998) Selective interference of beta-arrestin 1 with kappa and delta but not mu opioid receptor/G protein coupling. J Biol Chem 273:24328-24333.

Connor M, Osborne PB, Christie MJ (2004) Mu-opioid receptor desensitization: is morphine different? Br J Pharmacol 143:685-696.

Dang VC, Christie MJ (2006) Beta-arrestin-2-independent regulation of mu opioid receptor. Soc Neurosci Abstr 32:426.11.

Dang VC, Williams JT (2004) Chronic morphine treatment reduces recovery from opioid desensitization. J Neursoci 24:7699-7706.

Diverse-Pierluissi M, Inglese J, Stoffel RH, Lefkowitz RJ, Dunlap K (1996) G protein-coupled receptor kinase mediates desensitization of norepinephrine-induced Ca2 + channel inhibition. Neuron 16:579-585.

Eitan S, Bryant CD, Saliminejad N, Yang YC, Vojdani E, Keith D Jr, Polakiewicz R, Evans CJ (2003) Brain region-specific mechanisms for acute morphine-induced mitogen-activated protein kinase modulation and distinct patterns of activation during analgesic tolerance and locomotor sensitization. J Neurosci 23:8360-8369.

Erdtmann-Vourliotis M, Mayer P, Ammon S, Riechert U, Hollt V (2001) Distribution of G-protein-coupled receptor kinase (GRK) isoforms 2, 3, 5 and 6 mRNA in the rat brain. Brain Res Mol Brain Res 95:129-137.

Fan XL, Zhang JS, Zhang XQ, Yue W, Ma L (2003) Differential regulation of beta-arrestin 1 and beta-arrestin 2 gene expression in rat brain by morphine. Neuroscience 117:383-389.

Finn AK, Whistler JL (2001) Endocytosis of the mu opioid receptor reduces tolerance and a cellular hallmark of opiate withdrawal. Neuron 32:829-839.

Gainetdinov RR, Premont RT, Bohn LM, Lefkowitz RJ, Caron MG (2004) Desensitization of $\mathrm{G}$ protein-coupled receptors and neuronal functions. Annu Rev Neurosci 27:107-144.

Ishimatsu M, Williams JT (1996) Synchronous activity in locus coeruleus results from dendritic interactions in pericoerulear regions. J Neurosci 16:5196-5204.

Johnson EA, Oldfield S, Braksator E, Gonzalez-Cuello A, Couch D, Hall KJ, Mundell SJ, Bailey CP, Kelly E, Henderson G (2006) Agonist-selective mechanisms of mu-opioid receptor desensitization in human embryonic kidney 293 cells. Mol Pharmacol 70:676-685.

Koch WJ, Hawes BE, Inglese J, Luttrell LM, Lefkowitz RJ (1994) Cellular expression of the carboxyl terminus of a $\mathrm{G}$ protein-coupled receptor kinase attenuates $G$ beta gamma-mediated signaling. J Biol Chem 269:6193-6197.

Kovoor A, Celver JP, Wu A, Chavkin C (1998) Agonist induced homologous desensitization of mu-opioid receptors mediated by $\mathrm{G}$ proteincoupled receptor kinases is dependent on agonist efficacy. Mol Pharmacol 54:704-711.

Li AH, Wang HL (2001) G protein-coupled receptor kinase 2 mediates mu- 
opioid receptor desensitization in GABAergic neurons of the nucleus raphe magnus. J Neurochem 77:435-444.

Ligeza A, Wawrzczak-Bargiela A, Kaminska D, Korostynski M, Przewlocki R (2008) Regulation of ERK1/2 phosphorylation by acute and chronic morphine - implications for the role of cAMP-responsive element binding factor (CREB)-dependent and Ets-like protein-1 (Elk-1)-dependent transcription; small interfering RNA-based strategy. FEBS J 275:3836-3849.

Lin FT, Miller WE, Luttrell LM, Lefkowitz RJ (1999) Feedback regulation of beta-arrestin1 function by extracellular signal-regulated kinases. J Biol Chem 274:15971-15974.

Macey TA, Lowe JD, Chavkin C (2006) Mu opioid receptor activation of ERK1/2 is GRK3 and arrestin dependent in striatal neurons. J Biol Chem 281:34515-34524.

Mouledous L, Diaz MF, Gutstein HB (2004) Modulation of extracellular signal-regulated kinase (ERK) activity by acute and chronic opioid treatment in neuronal and glial cell lines. J Neurochem 90:1371-1377.

Ogier-Denis E, Pattingre S, El Benna J, Codogno P (2000) Erk1/2dependent phosphorylation of Galpha-interacting protein stimulates its GTPase accelerating activity and autophagy in human colon cancer cells. J Biol Chem 275:39090-39095.

Schmidt H, Schulz S, Klutzny M, Koch T, Händel M, Höllt V (2000) Involvement of mitogen-activated protein kinase in agonist-induced phos- phorylation of the mu-opioid receptor in HEK 293 cells. J Neurochem $74: 414-422$.

Schulz R, Wehmeyer A, Murphy J, Schulz K (1999) Phosducin, betaarrestin and opioid receptor migration. Eur J Pharmacol 375:349-357.

Shenoy SK, Lefkowitz RJ (2003) Multifaceted roles of beta-arrestins in the regulation of seven-membrane-spanning receptor trafficking and signalling. Biochem J 375:503-515.

Tan M, Groszer M, Tan AM, Pandya A, Liu X, Xie CW (2003) Phosphoinositide 3-kinase cascade facilitates $\mu$-opioid desensitization in sensory neurons by altering G-protein-effector interactions. J Neurosci 23:10292-10301.

Walwyn W, Evans CJ, Hales TG (2007) $\beta$-Arrestin2 and c-Src regulate the constitutive activity and recycling of $\mu$ opioid receptors in dorsal root ganglion neurons. J Neurosci 27:5092-5104.

Wang HL (2000) A cluster of Ser/Thr residues at the C-terminus of muopioid receptor is required for $G$ protein-coupled receptor kinase 2-mediated desensitization. Neuropharmacology 39:353-363.

Williams JT, Christie MJ, Manzoni O (2001) Cellular and synaptic adaptations mediating opioid dependence. Physiol Rev 81:299-343.

Zheng H, Loh HH, Law PY (2008) Beta-arrestin-dependent mu-opioid receptor-activated extracellular signal-regulated kinases (ERKs) translocate to nucleus in contrast to $\mathrm{G}$ protein-dependent ERK activation. Mol Pharmacol 73:178-190. 